Received May 31, 2010

Revised August 31, 2010

Accepted September 9, 2010

\title{
A Behavioral Economics Study of How US Trade Deficits with Asia Result in Hate Crimes in the US
}

\author{
JOHN MIRIKITANI*
}

Free trade is a sacred shibboleth to economists, but this paper is a behavioral economic analysis which points out a psychological flaw based on the phenomenon of Frustration-Aggression, illustrating how US trade deficits with Asia-Japan, Korea, and China-cause generalized economic frustration in the US and hence are significantly related to all types of hate crimes. This is similar to the history of pre-WWII Germany. However, Japanese companies, by locating substantial production facilities to the US, have been able to significantly reverse this phenomenon. China's trade deficit, largest vis-a-vis the US, shows a strong relationship with hate crimes in the US. In contrast, Korea was an ally of the US unlike Japan and China, with a relatively small trade deficit with the US, and so does not suffer from the stigma of other Asian Countries.

Keytuords: Free Trade, Protectionism, US trade deficits with Asia, Compensation Principle, FDI, Political Correctness, Criminology of US hate crimes, Behavioral Law and Economics, Behavioral Economics, Frustration-Aggression Hypothesis, Social Learning, Fight or Flight Response, Fundamental Attribution Error, Situationism, Porter Hypothesis, Psychological Diplomacy, Complex Interdependence, United States, Japan, Korea, China

Assistant Professor, International Trade and Business Hallym University, South Korea; E-mail: mirikitani@hallym.ac.kr 


\section{INTRODUCTION}

$\mathrm{U}$

$S$ trade deficits with Asia have caused many angry statements in the US, blaming various Asian countries for 'stealing US jobs,' that the economics behind the rhetoric angers people enough to commit actual crimes? Is it really true, as alleged by the US Civil Rights Commission, ${ }^{2}$ that it is the statements made by US politicians and business leaders that are the major factor in hate crimes, or is it in reality the economic phenomenon of trade deficits, combined with the psychological feeling of economic frustration, which drives both the angry statements by politicians and business leaders as well as hate crimes? Is there a flaw in the argument for free trade taught in traditional economics? The answer regarding the question of the 'real' cause of hate crimes should influence the choice of policies to combat hate crimes. In any case, the theory of what causes hate crimes is still an unresolved and open question for researchers: the field is in need of a model. The field has basically attempted to develop a theory of the links between economics and frustration based on microeconomic data. On the other hand, this paper investigates the existence of a strong relationship discovered between the macroeconomic variable of trade deficits from Asia-Japan, Korea, and China-and hate crimes in the US committed because of a victim's race, religion, sexual orientation, national origin, or disability status.

At first it might be surprising that the hate crimes caused by trade deficits go beyond just the race-Asian-American-of a victim, who is according to this limited view of human nature, scapegoated for being from the same race as those creating huge trade deficits with the US. Nevertheless, when committing acts of aggression, humans are not so rational as to select victims who allegedly 'cause' the problem, for example, by scapegoating only Asians in retaliation for trade deficits with Asia, but in reality a broadly-based economic frustration caused by being the 'loser' in free trade leads to hate crimes against all weak minorities-not only Asians. According to animal experiments on the well-known Frustration-Aggression Hypothesis in psychology, acts of aggression tend to be much more indiscriminate in nature, impulsive, and can be directed at any object in proximity-or displaced-by the offender, who is broadly frustrated.

When the true causes of various hate crimes is known to be economic, it may become possible to organize all groups who are discriminated against in order to unify the various minority groups and form an effective advocacy group, addressing the real underlying cause of their problems. In other words, this paper might be interpreted as evidence for why a general philosophy of political correctness' might be an appropriate response to the broad, all-encompassing economic causes of hate crimes, rather than taking a piecemeal approach to each victim group since the underlying cause may be the same: i.e. the economics of widespread frustration caused by trade deficits. As an alternative this paper 
could be interpreted as justifying extensive use of the 'compensation principle' or social welfare, as in Canada, in order to address any economic frustration and friction caused by free trade.

To place the contentions of this paper in a historical context, and to give intuition for the results, the same phenomenon as that described in this paper using recent data from the US also occurred in pre-WWII Germany. During the rise of Nazism, widespread economic frustration was apparcnt, caused by an 'inferior' position in the international economy, with reparation payments imposed by the Treaty of Versailles; domestic scapegoats thus were Jews, homosexuals, Gypsies, and the mentally and physically challenged. In fact, the types of scapegoats used by the Nazis were identical to the types of minorities used in the modern definition of hate crimes-offenses based on race, religion, sexual orientation, national origin, and disability. Note that 'Jews' fall into the modern categories for 'race/religion'; while 'homosexuals' fall under the rubric for 'sexual orientation'; 'Gypsies' is a pejorative term for a group lacking 'national origin'; and finally those 'mentally and physically challenged' call into question 'disability.' Disturbingly, during the first year of the current Obama Administration, the number of hate groups-including Nazi groups-tracked by the Southern Poverty Law Center (which bankrupted the KKK through civil rights lawsuits) increased slightly, but the related 'nativist extremist' groups increased by $79 \%$, and the number of 'Militia'/'Patriot' groups have increased by $244 \%, 3$ Finally, the Nazis proclaimed-in a political sense correctly, according to this paper-that the reparations payments made to the foreign powers who were the enemies of Germany in WWI were experienced as particularly aversive and hence likely to result in widespread economic frustration because of the feelings of dishonor at having to make payments to former enemies. Note for future reference that this paper does in fact find a stronger relation between trade deficits and hate crimes for the former enemies of the US in Asia (Japan, China) instead of with a former ally (Korea), for which trade actually reduces hate crimes.

This is uncomfortably close to becoming a political reality, as even President Obama claimed during his campaign for President in 2008:

You go into some of these small towns in Pennsylvania, and like a lot of small towns in the Midwest [i.e., Michigan, Ohio, and Missouri-studied in this paper], the jobs have been gone now for 25 years and nothing's replaced them [emphasis added]. And they fell through the Clinton Administration, and the Bush Administration, and each successive administration has said that somehow these communities are going to regenerate and they have not. And it's not surprising then they get bitter. they cling to guns or religion or antipathy to people who aren't like them or anti-immigrant sentiment or anti-trade sentiment as a way to explain their frustrations ${ }^{4}$ [Emphasis added]. 
In other words, astute politicians have already taken notice of the link between unemployment caused by trade deficits and the sense of economic frustration directed at minority groups. This paper might therefore be seen as an exercise designed to more rigorously test the validity of the Political-Economic-Psychological intuition of current US President Obama on the origins of hate crimes in the US.

Further, there is evidence presented in this paper to suggest that rather than passively receiving the negative publicity which is inherent in such acts of aggression, companies can take effective measures to 'clear their own names' of this stigma. For example, according to this study, Japanese car manufacturers have found an effective managerial solution to the economic frustration in America that might be caused by their own success. Since the social unrest in America appears to be caused by the economics of trade deficits with the US, one solution is to build plants in the US to create jobs for Americans, which eliminates the economic frustration caused by trade deficits. Indeed, this reputational management might be the only incentive compatible, i.e. profitable, way to make real inroads into social unrest caused by trade deficits, since the analysis of the cause of social unrest advocated by the US Civil Rights Commission, i.e, the angry rhetoric of politicians and business leaders, may in reality be a symptom, and not the true cause, that is rooted in economics. Further, there may be political objections to a 'Social Welfare Net' or 'Political Correctness.' In other words, as matters now stand, the victims of hate crimes really must be forced to rely on the protection afforded them by for-profit motivations of foreign firms. This is a form of the so-called Porter Hypothesis, 5 which asserts that firms will engage in socially responsible behavior if it is profitable to do so.

The implication for companies, especially large exporting companies from Japan, Korea, and China, is that it may be desirable to prevent known sources of social unrest in the US caused by their exporting activities which result in economic frustration due to the trade deficits in the US-a matter which may be of national interest in order to secure a non-Protectionist US. In fact, there is evidence from this study that as China grows and is responsible for larger trade deficits in the US, exports from China will likely become the focus of what could be called a form of 'China Bashing,' just as the Japanese were subjected to 'Jap Bashing.' The economic frustration caused by trade deficits with Asia in the US have implications for the ease of the continued sustainable economic development and security of not only China, but Korea (and Japan, though for now its corporate strategy of building plants in the US appears to have worked to ease economic frustration), i.e. trade deficits with Asia could cause widespread economic frustration in the US that might result in opportunistic, populist politicians advocating more protectionism, which might hurt everyone. Further, these behavioral economic issues-which involve both psychology and economics-might 
affect the politically delicate FTA negotiations with Korea, as well as the complicated relations with the growing superpower that is China.

Furthermore, note that based on the many significant coefficients found for the model specification used in this paper, which purports to use a more correct specification of the causes of hate crimes by following the precepts of behavioral economics and the Frustration-Aggression Hypothesis, it appears that the FBI data on hate crimes are not mismeasured, as has been alleged by many critics. The problems that previous researchers encountered might have been due to using misspecified models, whose lack of fit was incorrectly ascribed to measurement error.

Finally, note that this paper relies upon a relatively short time series of 14-years, because the US FBI has only been gathering data on hate crimes from 1995-2008. However, due to the importance of the subject of hate crimes, and due to the ability of the model to achieve statistical significance with a parsimonious model, the data bear looking at closely, and trying to use the model to test future data, as it becomes available. The model is parsimonious, and uses only 4 explanatory variables-the trade deficits of the US with each of Japan, Korea, and China, as well as the lagged value of the dependent variable-to understand the 14-years of hate crime data, so hopefully the model is not subject to the objection from an econometric point of view that too many explanatory variables were used to predict too few data points. To address this problem, adjusted $\mathrm{R}$-squared are reported throughout this paper, which penalize attempts to add too many explanatory variables relative to the sample size. To preview the results, the adjusted $\mathrm{R}$-squared reaches about 0.80 in the baseline or normal case.

In general, this paper is aligned with the modern school of behavioral economics, which attempts to make realistic assumptions about human nature, based on psychology. Section I reviews the literature in psychology, economics, and criminology; section II describes the data; section III addresses the methodology; section IV presents an estimation equation for a robust yet parsimonious specification of the regression which is consistent with the field of behavioral economics; section V is discussion; and section VI concludes.

\section{LITERATURE REVIEW}

\section{Psychological Literature Revieu}

\section{(1) Social Learning Theory}

First, note that the Social Learning Theory (Badura, 1983) devised by a man whom many consider to be the greatest living psychologist, Albert Bandura, 
posits that humans have evolved in order to learn the fastest by using others as role models. In forensics, this phenomenon is known as a copycat crime (Berkowitz, 1962) in which one crime leads to imitation by others. For example, today in the state of Michigan, a well-known location for American car companies, we are currently witnessing the exposure of the race-hate group known as Hutaree. Hutaree is a copycat group with goals similar to the Michigan Militia, which reached a membership of 50.000 when Asian car companies made large inroads into the American car market in the period 1980-1990, allegedly causing high unemployment in Michigan. Thus, in the models used by the studies in this paper, the first explanatory variable is the 'lag' of one-period in hate crimes, since there is a tendency for people to imitate their predecessors and commit copycat crimes. In this model, behavior in the prior period could in part lead to crime being committed today. In fact. Bandura once argued that the Frustration-Aggression Hypothesis (below) should be augmented by the Social Learning Theory ${ }^{6}$ (Bandura, 1963).

\section{(2) Frustration-Aggression Hypothesis}

The Frustration-Aggression Hypothesis (Miller, 1941) developed by researchers at the Yale Institute of Human Relations (Dollar, Doob, Miller, Mowrer, and Sears, 1939) suggests that a frustrating experience will lead to aggressive behavior against 'others' in the environment. The classic animal experiment ${ }^{8}$ (Berkowitz, 1983) involves two animals-not necessarily of the same species-placed together in a cage, while an electrical shock is applied to one animal. Despite the differences in species, and despite previous peaceable relations when placed in the same cage, the animal which receives the electrical shock (which is the model for frustration) lashes out in an immediate and 'unjustified' physical attack on the other animal which occupies the same cage (personified in human terms, the shocked animal seems to scapegoat the other animal, or incorrectly blames it for the shock from the experimenter).

\section{(i) Competition as Frustration}

There are numerous studies which have shown that competition is a reliable cause of frustration' (Berkowitz, 1962). This paper extends results obtained from other areas of competition to economic competition, which may be the type of competition that has the most practical relevance. Indeed, the analysis of this paper might suggest that the consequences of free trade and competition have hitherto unrecognized disadvantages in that there might be increases in hate crimes for the country that is the 'loser' in trade.

(ii) Displacement of Aggression onto Different Targets/Weakness of Targets The definition of 'others' can be quite broad, which is shown by experiments 
with animals. And the psychological literature has long recognized that displacement can occur from the true causes of the frustration onto substitute targets, (Berkowitz, 1989). Indeed, it should be pointed out at this time (and emphasized again in the section on "Data") that the dependent variable in this study comes from the US FBI Uniform Crime Reports on all hate crimes-offenses based on race, religion, sexual orientation, national origin, and disability status-which ate a composite of offenses that the FBI collects data on by state, and then totals. Note that there are a minority of psychologists who believe that Frustration-Aggression should be directed at achieving some instrumental goal (Bandura, 1983). For example, consciously directing acts of aggression towards only Asian-Americans in the case of trade deficits with Asia because of the 'instrumental goal' of (supposedly) 'sending a signal' back to Asians by victimizing Asian-Americans. However, this interpretation is debatable and most authors argue for a broader range of 'targets' of Frustration-Aggression (Berkowitz, 1989).

The Social Learning Theory has shown that the likelihood of observing Frustration-Aggression depends upon 1) prior learning, 2) the presence of suitable targets, and 3) the availability of alternative responses (Bandura, 1973; Berkowitz, 1983). This paper fits within the framework of the Frustration-Aggression Hypothesis as modified by Social Learning Theory. In the case of hate crimes, the minority groups who are victims present opportune targets because they are unlikely to fight back due to their weakness. Weak groups are likely to become targets of an attack (Berkowitz, 1983). ${ }^{10}$ One study even found that disabled people receive more punishment from teachers for the same mistake (Berkowitz and Frodi, 1979). Furthermore, there are no practical ways for the average American to influence national decisions on trade deficits with Asia. Finally, recall that this paper takes into account prior learning by means of including a term for the role model effects from the previous year's level of hate crimes.

\section{(iii) Immediacy of Aggression}

In animal experiments and experiments with humans the Frustration-Aggression Hypothesis emphasizes the immediacy of an act of aggression. Thus, the present model uses levels of the trade deficits with Asia-comprised of the trade deficits with Japan, Korea, and China-in the same period as the commission of total hate crimes, since hate crimes are modeled as occurring at nearly the same time as the trade deficits. This topic will have special relevance to the Econometrics issues of 'endogeneity' and the existence of other unobserved variables that might be alternative causes of hate crimes.

\section{(iv) Mitigation of Frustration and Causation}

The psychological literature also proposed that the strength of the resulting 
instigation to aggression will be reduced by whatever 'partial gratifications' are obtained (Berkowitz, 1989). In other words, the 'partial gratifications' are logically a sufficient cause: in the current paper, money is a sufficient cause because reducing it causes frustration via trade deficits while increasing money as through Japanese companies locating in the US has the opposite effect. Thus, trade deficits/money are a sufficient cause of frustration in the US, and note for future reference that authorities in psychology helieve that if a policy can both incicase/decrease acts of aggression, then that policy is the causal mechanism that offers a way to control aggression. For purposes of this paper, it means that since the relationship between trade deficits and hate crimes can be reduced by the strategy of building plants in the US, then the likely cause of the frustration was also economic. This paper will go on to argue that trade deficits are also likely to be a necessary cause of hate crimes in the econometric literature section on endogeneity and causation.

(v) Aversiveness of Frustrating Event strengthens the link with Aggression There is an important extension of the original Frustration-Aggression Hypothesis that emphasizes that there must be an aversion to the source of the frustration in order to observe the link between Frustration-Aggression (Berkowitz, 1978, 1982, 1983, 1989).11

(a) Frequently mentioned criticism of the Frustration-Aggression thesis: Frustrations are not a very common or important antecedent of aggression. One cannot say in the abstract whether thwartings are weak or strong instigators to aggression. The likelihood that an unexpected barrier to goal attainment will give rise to an aggressive reaction depends on the azenszeness of this event [Emphasis added] (Berkowitz, 1984; Berkowitz and Heimer, 1989). 12

Aggression is instigated because of an aversive event that occurs when the event stimulates the well-known 'fight-or-flight' reaction (Berkowitz, 1983, 1988. 1989; Berkowitz and Heimer, 1989) that is instinctive in humans. Consistent with these aversive events leading to Frustration-Aggression is the experiment in which viewing a violent film facilitated the link between Frustration-Aggression (Berkowitz, 1964). ${ }^{13}$ There can be almost nothing as aversive and likely to prompt the fight-or-flight reaction as a World War. Thus, Americans fought the Japanese during WWII, and clearly experienced the fight-or-flight reaction produced by a World War, and hence they are likely to experience a trade deficit with Japan as aversive, which strengthens the link between Frustration-Aggression. Indeed, there are many references from the period of 'Jap Bashing,' corroborating that Americans felt that the Japanese were trying to win by means of trade 
deficits what they could not win by means of WWII. ${ }^{14}$ By contrast, America has never been at war with China (directly). For future reference, the data (Table 4) shows that Americans in the state of Michigan (MI) are much more averse to trade deficits with Japan than trade deficits with China, i.e. one additional hate crime occurs for every $\$ 247$ million increase in the trade deficit with Japan, while one additional hate crime occurs for every $\$ 542$ million increase in the trade deficit with China. Since China and the US are still involved in a Cold War,' China's Trade imbalances with the US still result in hate crimes in the US, but with a reduced intensity, relative to Japan's trade deficits. However, from 1950-53, the US fought for Korea, so the aversiveness of the trade deficits with Korea should be greatly reduced, and the Frustration-Aggression linkage is less likely to hold. This is in fact what happens (Table 4), since trade deficits with Korea actually reduce hate crimes. In other words the strength of the Frustration-Aggression Hypothesis varies with the aversion experienced, as predicted by psychologists, especially Berkowitz (1989).

In fact, to preview the results, there is a near perfect predictive relationship between historical aversitessness, i.e. previous enemy status in a war, and the relative magnitudes of the regression coefficients when these are used with the level of trade deficits to predict hate crimes in Michigan (the 'worst case') in 2008 (Table 4).

Thus, the Frustration-Aggression Hypothesis has high construct validity since it seems to explain many nuances or features in the data, which increases the likelihood that it is a good assumption on which to base research, since it is unlikely that so many relationships could be predicted by the Hypothesis unless the assumption is necessary.

\section{(vi) Causal Mechanism/Construct Validity}

Furthermore, regarding proof of a causal mechanism, several studies have proposed that the intensity of the aggression should vary directly with the source of the frustration (Dollard, Doob, Miller, Mowrer, and Sears, 1939; Buss, 1961). Note that, for future reference, this investigation does have high construct validity because the data shows (Table 1 and Table 2) that the countries-Japan, Korea, and China-that cause bigger trade deficits with the US in absolute levels-rather than intensity or USD per Hate Crime as in the previous paragraph-also cause greater economic frustration and have a closer relation to total hate crimes in US states, as measured by the t-stats. Further, US states which suffer greater economic frustration on account of trade deficits with Asia, such as Michigan, show a stronger relationship between trade deficits and state-level hate crimes.

In sum, the Frustration-Aggression Hypothesis in psychology does seem to produce a good fit for many of the nuances and features in the data relating trade deficits in Asia to hate crimes in the US, and hence it may be considered the 'necessary and sufficient' or 'scientific cause' of the relations in the data. 
TABle 1. OLS(N=13)

\begin{tabular}{|c|c|c|c|c|c|c|}
\hline & Constant & Lag & JPN Trdef & KR Trdef & CHN Trdef & Adj, R-sqd/P $>F$ \\
\hline \multirow{2}{*}{ MO } & $172.4151^{*}$ & 3119809 & .0008781 & $.005429^{\circ}$ & -.0002465 & \multirow{2}{*}{$0.7935 / 0.0016^{\circ}$} \\
\hline & $(t=2.67)$ & $(t=1.46)$ & $(t=0.457)$ & $(t=2.37)$ & $(t=-2.03)$ & \\
\hline \multirow{2}{*}{ MI } & $393.4863^{\circ}$ & -4483207 & -.0040483 & .0101303 & $-.0018473^{n}$ & \multirow{2}{*}{$0.7184 / 0.0053^{*}$} \\
\hline & $(t=2.20)$ & $(t=-1.08)$ & $(t=-1.30)$ & $(c=1.77)$ & $(t=-2.84)$ & \\
\hline \multirow{2}{*}{$\mathrm{OH}$} & $819.146^{\circ}$ & $-.6013809^{\circ}$ & .006749 & -.0091926 & -.000688 & \multirow{2}{*}{$0.2661 / 0.1744$} \\
\hline & $(t=3.50)$ & $(t=-2.13)$ & $(t=1.94)$ & $(t=-1.76)$ & $(\mathrm{t}=-1.80)$ & \\
\hline \multirow{2}{*}{$\mathrm{CA}$} & $2589.255^{\circ *}$ & -.0467469 & .002998 & .0259587 & .0025139 & \multirow{2}{*}{$0.5837 / 0.0231^{*}$} \\
\hline & $(t=2.92)$ & $(t=-0.18)$ & $(t=-0.18)$ & $(t=1.43)$ & $(t=1.77)$ & \\
\hline
\end{tabular}

NOTE: Significant or marginally significant coefficients in boldface.

$\mathrm{p}<05 . \quad \mathrm{p}<.001, \quad \mathrm{p}<.001$

Breusch-Godfrey Test for Autocorrelation. H0: No Autocorrelation. Probability $>$ chi-squared. All regressions insignificant.

\begin{tabular}{ll}
\hline OLS & \\
\hline MO & 0.5724 \\
MI & 0.1553 \\
OH & 0.2931 \\
CA & 0.2830 \\
\hline
\end{tabular}

\section{Economics Literature Revieu}

(1) Time Series Econometrics: Using OLS to measure Adjusted R-squared

Note at this time that this paper uses data in a Time Series, for the entire length of time (1995-2008 or 14-years) during which the US FBI has gathered data on hate crimes by state. Further this paper utilizes yearly data gathered by the US Census on the contemporaneous sizes of the trade deficits with Japan, Korea, and China (this will be explained again in the section on "Data"). The important point to note at this time is that both Time Series are macroeconomic data from within the same country/macroeconomy. Any attempt to analyze such macroeconomic Time Series often exhibits a spurious correlation (Granger and Newbold, 1974) because both dependent and independent variables might be influenced by the same business cycle, which causes them to rise and fall together. Thus, this paper uses as a control variable the lag (1-year) of the dependent variable, since if the dependent variable is influenced by the business cycle, then the lagged dependent variable used as an explanatory variable can capture the influence of the business cycle, a phenomenon which is known as autocorrelation, or how a variable is related to its own lagged values. That is, if a variable is autocorrelated, then a high/low value in period 1 is likely to be followed 
by a high/low value in period 2. Happily from the point of view of behavioral economics, the Social Learning Theory of copycat crimes (described above) argues for the same specification containing as an explanatory variable the lagged value of the dependent variable as do autocorrelation-corrected specifications used in applied macroeconometrics.

In order to analyze the Time Series data as simply as possible, the paper uses Regression with Ordinary Least Squares (OLS) and the slightly more advanced theory of Generalized Least Squares (GLS) or Feasible Generalized Least Squares (FGLS). FGIS is the application of data to estimate a GLS model, which has smaller standard errors and hence higher t-stats and thus produces greater measures of significance than OLS because GLS/FGLS adjust for heteroscedasticity and autocorrelation, Greene (2002). Note that this paper can use the well-known methods of regression because the data satisfy the technical conditions of what is called the Grenander-Rosenblat Theorem (Grenander and Rosenblatt, 1957; Phillips and Park, 1988) which says that the coefficients estimated by OLS are under technical conditions the same as those of GLS (Table 1, Table 2). Rather than go into the technical details under which OLS is equivalent to GISS, this paper simply shows that the empirical results demonstrate that the regression coefficients for OLS are the same as FGLS-even with only 14 observations. For practical purposes, the reason that we would like to use OLS instead of GLS/FGLS is that GLS/FGLS does not have an adjusted R-squared measure as OLS does, and adjusted R-squared is better for the data set of $T=14$ and 4 explanatory variables, since adjusted R-squared is a more conservative measure of Goodness-of-Fit, and adjusted R-squared penalizes the researcher who tries to use too many explanatory variables with too small a sample of data. For simplicity of presentation, this paper will not only cite the GIS/FGLS Chi-squared measure to assess Goodness-of-Fit, but also present the traditional adjusted $\mathrm{R}$-squared, which is nevertheless a respectable 0.80 in the baseline case for OLS (Table 1). Finally, in order to test for autocorrelation in the presence of a lagged dependent variable, a Breusch-Godfrey test is conducted on each OLS result. to show that the results obtained are robust to autocorrelation for all states (Table 1). Since GLS/FGLS are robust to autocorrelation relative to OLS, the FGLS results are presumed robust since the OLS results are all robust to autocorrelation.

\section{(2) Bootstrap Method for Small Samples'5}

The major difficulty for this paper to overcome is the fact that the Sample Size is $\mathrm{T}=14$ years, since the US FBI only started to gather data over the period 1995-2008. Some authorities recognize the validity of Time Series samples of only $\mathrm{T}=15$, but we have in this study an uncomfortably small-but nevertheless important-Time Series of length $T=14$. One Econometric technique used to 
deal with this problem is the Bootstrap Method, so-called because the researcher can 'pull himself up by the bootstraps' by simply resampling with replacement from the original sample. In effect, the information contained in the original (small) sample is preserved during the resampling (simulation) process, and the standard errors of the regression (needed for calculating the t-stats on the regression coefficients) can be estimated by a simulation procedure of as few as 50 (Efron, 1987), iterations which re-use the original samplc. It can be shown in theory (Efron, 1979) that the resampling/simulation will quickly converge to the actual standard errors, after only a few iterations of the simulation.

\section{(3) Endogeneity-not Anticipated under the Frustration-Aggression Hypothesis}

Since the Frustration-Aggression Hypothesis, described above, posits that there is a nearly immediate-and hence done without time to think, or on the 'spur-of-the-moment'-link between the frustrating circumstances and the act of aggression, there should be no problems with endogeneity, which is the bias which results when people have time to make a choice based on some unobserved part of the economic environment. Based on the Psychological Literature, there is simply no time to choose the precise victim in the model of Frustration-Aggression, potentially based on other factors in the environment.

Further, the extension of the Frustration-Aggression Hypothesis, as modified by Social Learning Theory, suggests that the link will be strongest when the source of the frustration is perceived as 'beyond the control of the individual." Following this line of reasoning, $\alpha$ hypothesis, if there is a substantial link between frustration and aggression, as found by this paper, then endogeneity is unlikely in that the frustrated individual does not even perceive the possibility of affecting trade deficits. Therefore, the econometric specification where the trade deficits are treated as exogenous-or imposed from outside-seems justified.

For technical econometric reasons, absence of endogeneity means that a 'dynamic' model of either OLS or FGLS, which uses as explanatory variable the lagged value of the dependent variable, as in the present paper, will yield consistent estimates (Greene, 2002).

\section{(i) Endogeneity and Causation}

Since the impulse to commit a hate crime occurs almost immediately or impulsively, according to psychologists, there is no time to consider many other factors in the decision. Therefore, assuming that the Frustration-Aggression Hypothesis is true, under this hypothesis there are not likely to be many other causes of the aggression. In fact, the adjusted R-squared in this study can go as high as 0.80 in the baseline case (Table 1), ruling out the need for investigation of many other major causes. Thus, unobservable, other factors are unlikely to have a major influence on the relationship between trade deficits and hate crimes. 
This helps to establish that the explanatory variables identified are likely to be the major necessary causes of hate crimes, as well as sufficient causes (see Psychological Literature, above). Recall that in the section on Psychological Literature, the psychological mechanism that lead to many minority groups suffering hate crimes from economic frustration was a combination of (1) their weakness (or minority status), (2) the inability of offenders to influence the frustrating event, and (3) the copycut un sucial learning quality of offenses. These may be the abstract psychological qualities that are other necessary causes for the validity of the Frustration-Aggression Hypothesis, but the findings of this paper are that these may not be as important as the economic frustration caused by trade deficits. For example, this paper includes a term for copycat crimes by including the lagged value of hate crimes in the previous year, but this achieves significance in only 1 of 4 states, and has the theoretically 'wrong' sign (OH, Table 1, Table 2). Further, the Marxist-Institutional Criminologists have tried to focus on cause 1 and cause 2, above, with limited success (see next section).

\section{Criminology Literature Revieu}

The schools of criminology, from the perspective of economics, are divided into 2 opposing camps: the Marxist-Institutionalist school, and the Chicago School.

\section{(1) Existing Theories of 'hate crimes' are Inadequatel6}

\section{(i) Social Structural/Institutional Theories}

Many-if not all-of the 'Social Structural' or 'Institutional' theories of criminology agree that economics is one element of the structures which cause an individual to commit crime, as argued by Marxists. But none rely solely on the economics of trade deficits and psychology, as this paper attempts to do, perhaps because such theories focus on local/neighborhood poverty and give a powerful role to policy failure by the State, rather than considering the clear impact of trade deficits on local poverty. These theories 'miss the forest for the trees.'

\section{(ii) Rational Choice Theory}

A natural outgrowth of the prominent use of economics in structural or institutional Theories of the Marxist persuasion is the intellectual attempt by economists to base their theories of crime on purely microeconomic variables and 'rational' optimization by individuals rather than the State. This Chicago School theory is associated with famous economists from the University of Chicago, such as Nobel Prize Winners Gary Becker (Becker, 1968) and George Stigler (Stigler, 1970), and puts microeconomic variables at center stage. However, the Chicago 
School of Economics traditionally de-emphasizes the need for making realistic assumptions of actual behavior, which is instead the paradigm advocated by the modern school called behavioral economics.

\section{(iii) Contemporary Critical Criminology}

Interestingly, Contemporary Critical Criminology is a reaction to the unrealistic assumptions made about haman behavior by Chicago School economists. This is paralleled by criticisms from within the discipline of economics itself regarding the realism of the simplifying assumptions used by traditional economists. Indeed, the most cited paper in contemporary economics is not by an economist, but instead was written by two psychologists (Kahnman-Tversky, 1979), one of whom who is the only psychologist in history ever to be awarded the Nobel Prize in economics. That paper inspired the school of behavioral economics, a school which tries to introduce more realistic assumption about actual behavior into economics, as the present paper attempts to do.

\section{(iv) Behavioral Economics}

This paper is consistent with the school of behavioral economics, since it tries to simplify behavior as economists by focusing on Economic variables; however, it is unlike the Chicago School by attempting to make behavioral assumptions with actual-rather than positive/mathematically convenient-validity. Thus, this paper identifies a crucial concept from psychology, the Frustration-Aggression Hypothesis, and proceeds to analyze hate crimes using the assumptions about behavior from the Frustration-Aggression Hypothesis, as well as standard econometric techniques (see for example the above analysis of endogeneity and the immediacy of Frustration-Aggression).

\section{(a) Fundamental Attribution Error}

The Fundamental Attribution Error analyzed by behavioral economics seems to explain why it is that previous schools of Criminology, i.e. the Structural/ Institutionalist (Marxist) school and the diametrically opposed Chicago School (Capitalist) both have not arrived at the conclusions of this paper, but have settled for stories consistent with their views, though not entirely empirically sound. The Fundamental Attribution Error is that behavior is too often thought to be determined by the individual actor-whether institutional or human-rather than the situation. In the case of Marxists, this seems to result in a focus of how the Government under capitalism fails to protect certain weak minorities from oppression, i.e. based on race, religion, national origin, gender orientation, and disability status. And capitalism believes in the fairness of its system of economic justice to the individual consumer. But this paper may be among the first to examine the situational factors of trade deficits that cut across all hate crimes, rather than to focus on individuals or individual institutions. In 
a sense this paper is an antidote for the Fundamental Attribution Error made by past researchers into the criminology of hate crimes.

\section{DATA}

The dependent variable is the total of all types of hate crimes-offenses against any race, religion, sexual orientation, national origin, or disability status-from the US FBI "Uniform Crime Reports" from 1995-2008.17 Further, the US Census Department apparently considers it an important enough subject to gather year-by-year-not just decennial-data on the trade deficit/surplus with practically all other countries which are involved in trade with the US. The trade deficit data were gathered from the US Census over the period 1995-2008 from Japan, Korea, and China, 18 and serve as the major explanatory variables.

The key is to look at states within the US which have either ties to the American 'Big 3' car companies, or in the alternative ties to the Japanese (now Korean) car companies which have located in the US, as a response to the perception among some politicians and car buyers (who respond to the slogan 'Buy American') that Japanese car companies 'steal jobs' from the US. Another way this paper exploits state-level variation in the data is to find a state in which there are many Asian-Americans, and many Asian-American businesses, in order to investigate whether there is evidence that Americans really commit hate crimes not because of trade deficits with Asia but rather because they are jealous of the economic successes of Asian-Americans.

Although pooling the data at a National-level might in theory increase the statistical power of this study, it is much more interesting to examine the variation at the state-level in order to investigate whether trade deficits with Asian countries result in hate crimes. Therefore, we use data from the FBI on hate crimes from the following states.

\section{Michigan(MI)}

Michigan is of particular interest because for decades it has been the state associated most closely with the American automobile industry or 'Big 3' (GM, Ford, and Chrysler). Clearly, in Michigan, economic frustration may result for workers from the economic losses associated with greater trade deficits with Asia-especially in cars-which currently cause Michigan to have the highest statewide unemployment rate ${ }^{19}$ in the US. Thus, we expect there to be many acts of aggression or hate crimes committed in Michigan, connected to trade deficits with Asia. Indeed, anecdotally, Michigan has witnessed the commission of many serious hate crimes over the past 30-years, particularly against Asians or Asian products. For example, the 1982 cause aldore case of Vincent Chin, 20 that infamously 
resulted in his being beaten to death at the hands of an unemployed autoworker and a supervisor for an auto company. The defendants tried to claim in court that they had killed Vincent Chin because he had "looked Japanese." Note at this point that the results in this study point to an abiding antipathy among residents of Michigan not only towards Japan, whose car companies have succeeded in counteracting the economic frustration felt by residents of Michigan by building plants in the US (this study shows using data from neighiboring Ohio), but perhaps an even greater antipathy towards China (measured in absolute levels of trade deficits and hate crimes) which causes an even larger trade deficit for the US (Table 1-Table 3). Thus, ironically, Vincent Chin did not prevent the hate crime against him by trying to claim, "I'm not Japanese, I'm Chinese." You might say, according to this study, that he made matters worse and only 'jumped from the frying pan into the fire.'

Further evidence of the copycat nature of hate crimes was illustrated in early 2010, when the FBI exposed a plot by the race-hate group based in Michigan, called Hutaree, allegedly to assassinate law enforcement personnel. Interestingly, the current unemployment rate in Michigan during the time of the Hutaree incident in 2010 is almost the same at around $16 \%$ as the unemployment rate during the time of the Vincent Chin affair in 1982,21 suggesting that an economic motivation underlies these acts of aggression, i.e. trade deficits with Asia.

\section{2. $\mathrm{Obio}(\mathrm{OH})$}

Ohio is a very interesting state to compare with Michigan in its responses to trade deficits with Asia, because the cultures of Michigan and Ohio are practically the same, thus making it an excellent control. However, there is one crucial difference: Ohio has an established reputation as being 'friendly' to Japanese Foreign Direct Investment (FDI), and in fact Honda built the first Japanese-owned plant in the US in Marysville, Ohio in 1982.22 Additional Honda plants were built in Ohio in 1985 and 1989, leading to more Japanese automobile FDI in Ohio than in any other state. Thus, Ohio will prosper economically along with Japanese FDI and trade deficits between the US and Japan. It bears repeating that ironically Ohio is just south of the border to Michigan, and is therefore similar in many ways to Michigan-a natural experiment that largely obeys the ceteris paribus assumption of economics-except that Ohio and Michigan have vastly different perceptions of the trade deficits with Asia. In fact, note at this time that in this study the results indicate that the hate crimes that result from trade deficits with Japan (though not Korea and China, which do not have significant FDI in the US) are significantly higher in Michigan, while being significantly lower in Ohio (Table 1 and Table 2). 


\section{Missouri(MO)}

Missouri serves as the baseline state, since it is the most typical of the United States. ${ }^{23}$ For example, Missouri is a political bellwether state, since the Missouri choice for US President has accurately predicted the winner of the US Presidency for every election since 1904, with only two exceptions.

\section{California (CA)}

California has by far the most Asian-American businesses in the US, both as a percent of businesses $(33.7 \%$ ) and as a percent of receipts $(38.5 \%) .24$ The next closest state is New York, where Asian-American businesses and receipts are, respectively, $13.1 \%$ and $9.3 \%$. Thus, California data on hate crimes serves to test the alternative hypothesis that hate crimes in the US may in reality be due to the resentment over the success of Asian-American immigrants. Note that there was one joint venture in California created by Toyota-GM called NUMMI (New United Motor Manufacturing, Inc.), but relative to the size of the Californian economy, this one plant should be insignificant. In fact, GM pulled out of NUMMI in 2009, and Toyota is scheduled to abandon operations at the plant in 2010. Therefore, California would appear to present an almost clear-cut case where bias against economically successful Asian Americans might cause hate crimes, with no confounding effect from FDl from Asia (mostly from Japan).

\section{Accurate Data on Asian-American Population and Japanese FDI Unavailable}

Note that there is no control variable for the Asian population in each state. This data would come from the US Census, which is decennial, for example, conducted in 1990 and 2000 . Therefore, the data from intermediate years would have been inferred from an artificial process of linear interpolation, which is likely to suffer from inaccuracy. In addition, the variation that does exist is likely related to the birth rate and death rate among Asian-Americans, thus any variation in the data on percentage Asian-American is likely to result from the young/old, who do not pose a significant threat to the economic health of the US. The truly relevant economic variable are the receipts earned by Asian-American businessmen, who are of 'prime' working age, which is really a significant factor only in the state of California. Further, adding another variable to the regression would further reduce the degrees of freedom, which would reduce adjusted $\mathrm{R}$-squared, and thus reduce the overall explanatory power of the regressions.

Accurate data on the exact levels of Japanese FDI were not available. Further, the case of Ohio reveals that Japanese FDI is highly collinear with the trade 
deficit with Japan: one variable considers how much comes into the US from Japan, and the other variable considers how much money leaves the US for Japan. Thus, rather than adding another variable, a convenient approach to conserving degrees of freedom was to analyze the data using the same econometric model, but applying it to different states.

Thus, this paper pursues a strategy of exploiting the natural variability found in the states: Missouri is used as a bascline, because it is representative of the US; Michigan is used to test the effect of trade deficits on hate crimes, because of its historical tendency to commit hate crimes; Ohio is used to determine the effects of FDI by the Japanese car companies, which are heavily based there (as well as being across the border from Michigan); and California is used to test the effect of having a large share of state Receipts come from Asian-American businessmen, in order to answer the objection about whether the link between hate crime and trade deficits is really due to jealousy caused by the economic success of Asian-Americans.

\section{METHODOLOGY}

OLS and FGLS were used to regress the Total Hate Crimes over the period 1994-2008-comprised of combined offenses against race, religion, sexual orientation, national origin, and disability status-for several states (listed above) on a constant, plus the lagged value of the dependent variable, plus the US trade deficits/surpluses for each of Japan, Korea, and China over the same period. Except for the lagged dependent variable, these explanatory variables were from the same period as the dependent variable, since the Frustration-Aggression Hypothesis posits an immediate response (hate crimes) to frustration (trade deficits) in the same period. Note that the lagged value of the dependent variable was used as a control for autocorrelation induced by the business cycle. Again, note that the lagged dependent variable also captures the role model or copycat effects expected from Social Learning Theory.

OIS and GLS/FGLS Regression on a Time Series was justified by the GrenanderRosenblatt Theorem, which says that OLS and GLS/FGLS converge to the same coefficients on the explanatory variables-although the t-stats will be higher for GLS/FGLS, which adjusts the standard errors for autocorrelation and heteroscedasticity (which is the variability of standard errors over time, but assumed constant by OLS). As an empirical test, both OLS and FGLS were conducted, in order to show that both methods yielded the same coefficients (this was true in all cases), even though the number of observations was small $(\mathrm{T}=14)$. However, OLS allows the calculation of well-known adjusted R-squared measures for comparing models based on Goodness-of-Fit, whereas GLS/FGLS uses a less-familiar Chi-squared statistic, which does not adjust for the loss in degrees of freedom caused by having too many explanatory variables relative to the sample 
size as does adjusted R-squared. So, to ensure a conservative interpretation with a small sample for an important subject, i.e. hate crimes, the adjusted R-squared was reported for OLS, since adjusted R-squared accounts for the reduction in degrees of freedom caused by having many explanatory variables relative to the size of the sample $(T=14)$.

In order to correct statistically for the somewhat small sample size of $\mathrm{T}=14$, the Buotstrap Method was used in order to take 50 simulations of the regression using FGLS, each iteration drawing from the same $\mathrm{T}=14$ values (resampling) with replacement after each draw.

\section{Hypotheses}

Hypothesis 1: Michigan will exhibit a more significant relationship between trade deficits and hate crimes. relative to the baseline. T-stats on Beta coefficients on trade deficits $(\mathrm{MII})>T$-stats Beta coefficients on trade deficits $(\mathrm{MO})$. In other words. Michigan is more sensitive to trade deficits with Asia. Hypothesis 2: Obio will exhibit a less significant relationship between the trade deficit with Japan and hate crimes than the baseline. due to FDI by Japanese companies. Beta JPN Tirlef $(O H)>$ Beta JPN Tidef $(M I)$-lbis is because US trade deficits with Japan is a negative value, bence a large positive cocfficient means significantly fewer bate crimes.

Hypothesis 3: California will exbibit a less significant relationship between trade deficits and bate crime. relative to the baseline. since people are accustomed to Asian-Amerian Businesses and Anti-Asian (or otber hate orimes) sentiment is not explained by reference to the success of Asian-Americans.

Note that because of the difference in the size of the states, the exact magnitude of the coefficients are not comparable, so t-stats-which do not have measures in real units-are used as the measure of sensitivity of hate crimes to trade deficits. However, it is still possible, as in the cases of Michigan and Ohio, to test whether there is a significant change in sign of the coefficients. Note that no attempt is made to adjust the data by population of each state, since this study was not concerned with forecasting for a hypothetical population size, but rather analyzes the features of the linkage between trade deficits and hate crimes. Using this method, there is a natural interpretation of the regression coefficients as relating the size (in \$millions) of trade deficits to each additional hate crime (Table 4).

\section{ECONOMETRIC MODEL}

$$
\begin{aligned}
Y_{\mathrm{t}}= & \text { const }+\beta_{1} Y_{1-1}+\beta_{2} \operatorname{TrdefJAPAN}+\beta_{3} \operatorname{TrdefKOREA}, \\
& +\beta_{1} \operatorname{Trdef} X N A_{\mathrm{t}}+\epsilon_{\mathrm{t}}
\end{aligned}
$$


Where $\mathrm{Y}$ is Total Hate Crimes by state (MO-Missouri, Ml-Michigan, OH-Ohio, and CA.California), and the Trdef denotes the contemporaneous trade deficit caused in the US by each Asian country-Japan, Korea, and China.

\section{DISCUSSION}

In genetal, under almost every econometric technique, the model specification exhibits either a good overall fit or many significant coefficients (Table 1-Table 4). OLS and FGLS coefficients are exactly the same, therefore an appropriate measure of overall goodness-of-fit is the OLS measure of adjusted R-squared, which adjusts for the small sample size, relative to the number of explanatory variables. In the baseline case of Missouri, adjusted R-squared is very close to 0.80 (Table 1), which is to say that $80 \%$ of the variance is explained. The Breusch-Godfrey tests for autocorrelation are all negative (Table 1), thus there is no significant confounding effect from the business cycle. Therefore, the model appears robust. FGLS has the most significant coefficients $(16 / 20)$; however, the coefficients lose some significance when the standard errors are simulated with the Bootstrap Method, aithough the overall regressions remain significant. Another preliminary observation to make is that, although other scholars have often complained that hate crimes are mismeasured, it appears from the results of this paper, which purports to have a more accurately specified model, consistent with the modern approach of behavioral economics, that there is unlikely to be measurement error in the Hate Crime Statistics: the previous models might have been misspecified. In the following, I will discuss the FGLS specification, since it has the most significant coefficients. Further, it seems prudent that due to the significance of hate crimes, the most significant results should be discussed, in order to prevent the worst cases.

$\mathrm{Hl}$ is that Michigan will be more sensitive to trade deficits, relative to the baseline state of Missouri, and it receives support in 2/3 of the cases Japan and China, according to the significance of t-stats, Table 2). Note that Michigan is even more scnsitive (in an absolute sense of trade deficits causing more hate crimes-rather than measuring the intensity of hate crimes per dollar of the trade deficit) to the trade deficit with China as opposed to Japan. This is intuitive since the US in fact has had a bigger trade deficit with China since 2000 .

$\mathrm{H} 2$ is that Japanese companies are able to buy off the bad feelings caused when they displace Americans out of work, by simply locating plants in the US and creating American johs. This is strongly confirmed since the coefficient on JPN Trdef frum Michigan, which is at least marginally significant or significant and negative (meaning that trade deficits with Japan, which are also given by negacive numbers, tend to increase hate crimcs in the US), changes its sign

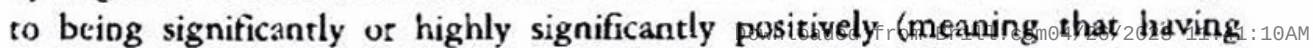


more FDI with Japan decreases hate crimes by creating jobs in the US), which is clearly a highy significant reversal of sign (Table 2). This finding is all the more powerful because Ohio is the state next to Michigan, so their cultures are almost identical-with the exception of Japanese FDI, which is much more prevalent in Ohio. Ohio thus serves as a natural experiment in which to test the effect of Japanese FDI on hate crimes in the US.

TABle 2. $\operatorname{GLS}(\mathbf{N}=13)$

\begin{tabular}{|c|c|c|c|c|c|c|}
\hline & Constane & Lag & JPN Tedef & KR Trdef & CHN Trdef & $P>$ Chi-sqd \\
\hline \multirow{2}{*}{ MO } & $172.4151^{* * t}$ & .3119809 & .0008781 & $.005429^{\circ *}$ & $-.0002465^{\circ "}$ & \multirow[t]{2}{*}{$0.0000^{\cdots \cdots}$} \\
\hline & $t t=3.41)$ & $(t=1.86)$ & $(t=1.00)$ & $(t=3.02)$ & $(t=-2.59)$ & \\
\hline \multirow{2}{*}{ MI } & $393.4863^{* *}$ & -.4483207 & -.0040483 & $.0101303^{\circ}$ & $-.0018473^{\cdots \cdots}$ & \multirow[t]{2}{*}{$0.0000^{4 *}$} \\
\hline & $(t=2.81)$ & $(t=-1.38)$ & $(t=-1.65)$ & $(t=2.26)$ & $(t=-3.62)$ & \\
\hline \multirow{2}{*}{$\mathrm{OH}$} & $819.146^{\circ * 4}$ & $-.6013809^{10}$ & $.006749^{44}$ & $.0091926^{\circ *}$ & $-.000688^{\circ}$ & \multirow[t]{2}{*}{$0.0088^{\circ-}$} \\
\hline & $(t=4.47)$ & $(t=-2.72)$ & $(t=2.47)$ & $(t=-2.25)$ & $(t=-2.29)$ & \\
\hline \multirow{2}{*}{$\mathrm{CA}$} & $2589.255^{* *}$ & -.0467469 & -.002998 & $.0259587^{\circ}$ & $.0029513^{\circ *}$ & \multirow[t]{2}{*}{$0.0000^{500}$} \\
\hline & $(t=3.72)$ & $(t=-0.23)$ & $(c=-0.32$ & $(t=1.82)$ & $(t=2.25)$ & \\
\hline
\end{tabular}

NOTE: significant of marginally significant coefficients in boldface.

$: \mathrm{p}<05: \mathrm{a}_{\mathrm{p}}<.01,{ }^{\cdots *}: \mathrm{p}<.001$.

H3 is that California, with its high percentage of Asian-American businesses, will be less scnsitive to trade deficits from Asia than the baseline case of Missouri. This does in fact occur in the cases of $2 / 2$ significant coefficients (for Korca, China), as measured by t-stats (Table 2). Californians are frustrated neither by trade deficits with Asia nor the economic success of Asian-Americans. As per their reputation, Californians are 'laid back' about things, a finding which actually enhances the construct validity of the paper.

Note that there is an indication that the relationship between trade deficits and US hate crimes is strengthening over time, as Table 4 shows. For 2008 in the stare of Michigan, the trade deficits of Japan, Korea, and China, taken cogether (without the intercept term), perfectly predict the actual number of hate crimes in Michigan: 619/619. Note that it is often the case that in regression the intercept is only statistical 'artifact' without interpretation, so this would appear to be the casc in the present paper.

\section{Results Mostly Preserved by Simulation with 'Bootstrap' Method}

The simulation preserves most of the results from estimation using FGLS (Table 4). First, the regression still shows that for the country with the biggest trade deficit with the US, i.e. China, the size of the trade deficit is still significantly related to all hate crimes in the US. Second, due the strategy of Japanese firms 
to build plants in Ohio, the sign of the coefficient that relates trade deficits with Japan and US hate crimes exhibits a significant reversal, such that trade deficits with Japan which result in increased hate crimes in Michigan actually reduce hate crimes in Ohio. Third, California is still a 'laidback' state when it comes to trade deficits with Asia: hate crimes are not significantly related to trade deficits with Asia. Fourth, Korea, a former ally of the US, shows the weakest relationship of any country betwcen trade deficits and hate crimes in the US, compared with Japan and China, which were adversaries of the US during WWII and the Cold War, respectively.

\section{The Rise of China Seems to Cause Great Frustration in the US, Resulting in More Bate Crimes}

The effect of the trade deficit with China is highly significant or significant for almost all countries under all methodologies (Table 1-Table 3). This is an extremely robust finding and serves to illustrate how economically 'sensitive'-but not necessarily 'rational'-people are and specifically how sensitive they are to the country causing the biggest trade deficit with the US. Note that the effect of trade deficits on hate crimes is a hitherto unexplored behavioral economic approach taken to explaining hate crimes: in this paper, traditional economic variables are shown to result in 'irrational' behavior. China provides the clearest evidence for this behavioral economic approach.

Further, the Bootstrap method may be proven valid by the 'reasonableness' of the results regarding China, under the Frustration-Aggression Hypothesis, which among all countries causes the biggest trade deficit with the US, and even under repeated simulation retains a significant relation to hate crimes in all US states (Table 3).

TABLe 3. FGLS WITH BoOstrappei) S.E.S (50 Rfyetstions)

\begin{tabular}{|c|c|c|c|c|c|c|}
\hline & Constant & Lag & JPN Trdef & KR Trdef & CHN Trdef & P $>$ Chi-sqd \\
\hline MO & $\begin{array}{c}172.4151 \\
(t=1.64)\end{array}$ & $\begin{array}{l}0.3119809 \\
(\mathrm{t}=1.23)\end{array}$ & $\begin{array}{l}0.0008781 \\
(t=0.58)\end{array}$ & $\begin{array}{c}0.005429 \\
t c=1.30\end{array}$ & $\begin{array}{l}-0.0002465 \\
(c=-1.61)\end{array}$ & $0.0065^{\circ *}$ \\
\hline MI & $\begin{array}{c}393.4863 \\
(t=1.62)\end{array}$ & $\begin{array}{l}-0.4483207 \\
(t=-0.83)\end{array}$ & $\begin{array}{l}-0.0040483 \\
(t=-1.26)\end{array}$ & $\begin{array}{l}0.0101303 \\
(c=1.05)\end{array}$ & $\begin{array}{l}-0018473^{\circ} \\
(t=-2.32)\end{array}$ & $0.0000^{* *}$ \\
\hline $\mathrm{OH}$ & $\begin{array}{c}819.146^{\circ} \\
(t=2.99)\end{array}$ & $\begin{array}{l}-0.6013809 \\
(t=-1.81)\end{array}$ & $\begin{array}{c}0.006749 \\
t=1.80)\end{array}$ & $\begin{array}{l}-0.0091926 \\
(t=-0.83)\end{array}$ & $\begin{array}{c}-.000688^{\circ} \\
(t=-2.20)\end{array}$ & 0.1449 \\
\hline $\mathrm{CA}$ & $\begin{array}{c}2589.255 \\
(t=1.43 .)\end{array}$ & $\begin{array}{l}-0.0467469 \\
t c=-0.08)\end{array}$ & $\begin{array}{c}-0.002998 \\
(t=-0.226)\end{array}$ & $\begin{array}{l}0.0259587 \\
(t=1.02)\end{array}$ & $\begin{array}{l}0.0029513 \\
t t=1.02)\end{array}$ & $0.0073^{* *}$ \\
\hline
\end{tabular}

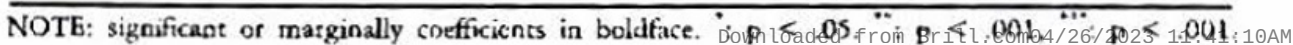




\section{Pasitive Feelings about Korea}

Probably because Korea has the smallest economy in Asia, among the countries under study, and partly because the US has maintained a trade surplus with Korea until as late as 1997 , Americans do not seem as frustrated by a trade deficit with Korea. Further, unlike Japan's role as an enemy in WWII, and unlike China's role as a rival during the Cold War, Korea was an ally of the US during the Korean War (1950-1953). Therefore, Korea does not have a historical connection to a major aversive event, i.e. it was never an enemy during a war, which would have triggered the well-known 'fight-or-flight' reaction and thereby strengthened the link between Frustration-Aggression. Indeed, with respect to Korea, it seems that a trade deficit actually results in fewer hate crimes, which is how trade is supposed to work in theory. But this study shows that there are cases where free trade runs afoul of the powerful Frustration-Aggression Hyporhesis.

\section{Construct Validity v. Actual Validity}

It is true that at the moment of the commission of the hate crimes under study, it is a practical impossibility to study the actual state-of-mind or detailed economic conditions of the perpetrator of a hate crime: we can as a practical matter observe only the size of the trade deficit or the rate of copycat crimes and try to link it to a hate crime via the psychologically valid phenomenon known as Frustration-Aggression.

This paper has indeed found that the greater the historically averse the relationship was with the US, the higher the sensitivity of hate crimes to trade deficits: there is about 1 Hate Crime committed for an increase of $\$ 250$ million in the trade deficit with Japan; while there is 1 additional Hate Crime for every $\$ 500$ million in the trade deficit with China; and there is 1 less hate Crime for every $\$ 99$ million increase in the trade deficit with Korea, i.e. the intensity of aversion is highest for Japan, lowest for Korea, and China is in between (Table 4). This is consistent with the fight-or-flight reactions or aversion in WWII with the former enemy Japan, the Cold War with China, and the Korean War in which Korea was an ally.

Thus, although actual validity might be impossible to prove, there is high construct validity to the approach taken in this paper: hate crimes seem to bear a linear relationship to the size of trade deficits with Asia, so that the bigger the trade deficit the stronger the relationship to hate crimes. Further, construct validity is increased since in the states of Michigan and Ohio, which are ceteris paribus the same except for Japanese FDI, the results of this paper have shown that the relationship between trade deficits with Asia and hate 
crimes can be reversed by a policy of FDI. Thus, it appears that what trade deficits do, trade surpluses undo, which 'makes sense,' and would thus appear to be the sufficient cause of hate crimes. This is especially so as the ceteris paribus cause is likely to have been isolated by a comparison between Michigan with Ohio, which are highly similar since they are next to each other.

TABll 4. Mi 2008 (Must Recent Data for the - Worst CaSE' StTAte)

\begin{tabular}{|c|c|c|c|}
\hline & JPN & KR & $\mathrm{CHN}$ \\
\hline Trdef w/US (mil): & -74120.4 & -13400.4 & -268039.8 \\
\hline \multirow[t]{2}{*}{ Coefficient: } & -.0040483 & $.0101303^{\circ}$ & $-.0018473^{\circ}$ \\
\hline & $(t=-1.65)$ & $(\mathrm{t}=2.26)$ & $(t=-3.62)$ \\
\hline Predicted Hate Crimes: & 300 & 136 & 495 \\
\hline \multicolumn{4}{|c|}{ (Total 659/659) Hate Crimes perfectly predicted by explanatory variables without intercep } \\
\hline $\begin{array}{l}\text { I additional Hate Crime from } \\
\text { increasing JPN/CHN Trdef by: }\end{array}$ & $\$ 247$ million & $\mathrm{n} / \mathrm{a}$ & \$542 million \\
\hline 1 less Hate Crime fr & $\mathrm{n}$ increasing $\mathrm{b}$ & Trdef: & $00 \mathrm{mil}$ \\
\hline
\end{tabular}

Further, Michigan was shown to be more sensitive than other states to trade deficits with Asia, as hypothesized, since it gets basically 0 FDI from Japan and is the home of the American 'Big $3^{\circ}$ car companies. The overall results point to the conclusion that the single dimension of an economic variable, i.e. money, either caused by a trade deficit with Asia or ameliorated by FDI, accounts for about $80 \%$ of the variance in hate crimes, even in the baseline case of Missouri.

\section{Scientific or 'Necessary and Sufficient' Causation}

The sufficiency of causation was proven by dual findings that (1) there is a significant relation found between large trade deficits and hate crimes in Michigan, and (2) Japanese FDI in Ohio has shown that this relationship can be significantly reversed by letting a state share in the economic benefits of trade, i.e. by FDI in the US. Thus, economics/money is shown to be the crucial factor that can both cause and prevent the phenomenon under study.

The necessity of causation is likely since the adjusted R-squared for the baseline regression is 0.80 , in other words most of the phenomenon has been explained and there is little room left for other causes than those in the model. Indeed, Table 4 shows that the size of the trade deficits with Japan, Korea, and China alone (without an intercept) can predict exactly the number of hate crimes in Michigan as recently as 2008. This might be because Michigan has suffered the worst economically from trade deficits. 
The high construct validity of the proposed model is proven by the manifold correct predictions it makes. First, the present study (Table 1-Table 3) shows that the bigger the trade deficits in absolute levels, then the more significant is the relation to hate crimes. Second, the present study (Table 4) shows that in the 'worst case' state of Michigan, the more aversive the relations with another country, i.e. whether there was war against that country, then less of a trade deficit that is required to cause an additional hate crime. Third, the present study (Table 1, Table 2) shows that the state of Michigan, which is the home of US automobile manufacturers, is more sensitive to trade deficits with Asia.

If the proposed model did not capture all the features in the data well, then it would be possible to argue that the failure to predict a feature of the data means that the major premise or assumption was false or unnecessary. The logical argument would be by angumention ad absurdam or contrapositive (If $A=>B$, then NOT $B=>$ NOT $A$ ). But, due to the high construct validity of the model, all the manifold predictions that follow from the initial assumption of the applicability of the Frustration-Aggression Hypothesis appear to be validated in the features of the data. Thus, it is difficult to argue by way of argumentum ad absurdum that the initial assumption was unnecessary.

\section{Exclusion of U.S. Unemployment as an Alternative Explanation}

There is an argument that might be advanced against the causal story advanced by this paper, namely, one could argue that the US unemployment per se was driving the results rather than US Trade Deficits with Asia. There are several arguments against this alternative explanation. In a future publication using the method of the present paper, it is shown that although Germany also causes a US Trade Deficit, it is not experienced as aversive, and does not cause Hate Crimes in the US. So, unemployment per se is not causing Hate Crimes, but rather the data in this paper shows that there is something more aversive about the US Trade Deficits caused by Japan and China, and this paper has argued that the US Trade Deficits caused by Japan and China are more aversive since these are former enemies of the US, as per the Berkowitzian extension to the Frustration-Aggression Hypothesis. Second, a control variable, $\mathrm{Y}(\mathrm{t}-1)$ or the lag of the Dependent Variable, already controls for all prior unobserved variables that might cause changes in the $\mathrm{Y}$-variable, including influences from the past history of unemployment. Third, the argument that the unemployment rate per se is an illogical way to explain Hate Crimes, according to theories based on the traditional Becker-type Rational Choice models of profit-maximizing criminals, since there is seldom a profit-motive involved in the Commission of a Hate Crime. 


\section{CONCLUSION}

This study shows the power of the approach to modeling known as behavioral economics. By making an empirically valid, i.e. psychological, assumption about human nature, nuanced effects of trade deficits on hate crimes become clear. It can now be presumed that the linkage between hate crime and US trade deficits with Asia have been put on a solid empirical foundation, subject to the caveat that results based on a small sample might become unreliable as more data are gathered. Nevertheless, due to the importance of the results and econometric checks for robustness, the author felt compelled to publish these results based on a small sample, as a possible warning to potential victims and society. Recall that an attempt was made to correct for the small sample size by using resampling with 50 iterations, and the results were robust to this simulation.

This paper tends to support the Theory of Complex Interdependence, which is major paradigm in international relations, since it links the traditional 'high' politics of war to what have been thought of as the 'low' politics of economics. Indeed, one might attempt to generalize the results of the current paper by claiming that free trade only benefits countries who were allies during war or that trade deficits are perceived as a continuation of the previous war. However, the successful trading relationship in the EU between historical enemies France and Germany suggests that further research is needed to determine whether generalization of this paper to other trading partners is warranted.

A somewhat startling implication of this paper is that, at least between former adversaries, free trade is not necessarily a good thing from the psychological perspective of this investigation into behavioral economics. Out of a sense of economic frustration at having once been the dominant economic superpower in the world, and having benefitted from the ideology of free trade, Americans now for the first time find themselves on the 'losing' side of free trade. This might psychologically be too difficult for some people to accept, and they turn their aggression against weak, identifiably different minorities, who serve as scapegoats. This is, of course, what lead to Nazism in Germany in pre-World War II, at the hands of an opportunistic populist politician who knew how to exploit mass feelings of economic frustration. The question becomes what is to be done to prevent the possibility of a political demagogue who rises to power by exploiting American feelings of economic frustration, and hence turning towards protectionism, which would hurt the economic development of the world.

In conclusion, this paper has tried to demonstrate that trade deficits with Asia when interpreted according to established results within the framework of the Frustration-Aggression Hypothesis, seem like good candidates for the 'necessary and sufficient' cause or 'scientific cause' of hate crimes, which might 
help to explain the 'failure' of current theories. Furthermore, during the recent G20 Summit held in Seoul over Nov. 11-12, Korea and the US failed to reach a Free Trade Agreement (FTA), which this paper points out is unfortunate since among major trading partners in Asia, only US Trade with Korea works according to the ideals of promoting Peace and Prosperity through Free Trade, since US Trade Deficits with Korea actually reduce US Hate Crimes.

\section{REFERENCES}

Ader, H. J., G. J. Mellenbergh, and D. J. Hand. 2008. Advising on Research Methods: A Consultant's Companion. Huizen, The Netherlands: Johannes van Kessel Publishing.

Azrin, N. H., R. R. Hutchinson, and R. Mclaughlin. 1965. The Opportunity for Aggression as an Operant Reinforce During Aversive Stimulation. Journal of Experimental Analysis of Behavior 8: 171-180.

Azrin. N. H., R. R. Hutchinson, and D. F. Hake. 1966. Extinction-Induced Aggression. Journal of the Experimental Analysis of Behavior 9: 191-204.

Bandura, Albert. 1973. Aggression: A Social Leaming Analysis. NJ: Prentice Hall. Bandura, Albert. 1993. Aggresion: A Social Leaning Analysis. Oxford: Prentice-Hall. Barron, R. A. 1977. Human aggression. New York: Plenum Press.

Becker, Gary. 1968. Crime and Punishment. Joumal of Political Economy 76(2): 196-217.

Berkowitz, Leonard. 1962. Aggression: A Social Psychological Analysis. New York: McGraw-Hill.

Berkowitz, Leonard. 1964. Aggressive Cues in Aggressive Behavior and Hostility Catharsis. Psychological Review 71: 104-122.

Berkowitz, Leonard. 1978. Whatever Happened to the Frustration-Aggression Hypothesis? American behavioral Scientist 21: 691-707.

Berkowitz, Leonard. 1982. Aversive Conditions as Stimuli to Aggression. In Advances in experimental social psychology, ed. Leonard Berkowitz. New York: Academic Press.

Berkowitz, Leonard. and A. Frodi. 1979. Reactions to a Child's Mistakes as Affected by Her/his Look and Speech. Social Psychology Quarterly 42: 420-425. Berkowitz, Leonard. 1983. Aversively Stimulated Aggression: Some Parallels and Differences in Research with Animals and Humans. American Psychologist 38: 1135-1144.

Berkowitz, Leonard. 1988. Frustrations, Appraisals, and Aversely Stimulated Aggression. Aggressive Behavior 14: 3-11.

Berkowitz, Leonard. and K. Heimer. 1989. On the Construction of Anger Experience: Aversive Events and Negative-Priming in the Formation of Feelings. In Advances in experimental and social psychology, ed. Leonard Berkowitz, New 
York: Academic Press, 22: 1-37.

Berkowitz, Leonard. 1989. Frustration-Aggression Hypothesis: Examination and Reformulation. Psychological Bulletin 106(1): 59-73.

Buss, Arnold. 1961. The Psychology of Agyression. New York: Wiley.

Coleman, James S. 1987. Micrefoundations and Macrosocial Behavior. In The mion-maar link, eds. Jeffrey C. Alexander, Richard Munch, and Neil J. Smelser. Berkeley: University of California Press.

Dill, Jody C. and Craig Anderson. 1995. Effects of Frustration Justification on Hostile Aggression. Aggressive Behavior 21: 359-369.

Dollard, J., L. Doob, N. Miller, O. Mowrer, and R. Sears. 1939. Frustration and Aggression. New Haven, CT: Yale University Press.

Efron, B. 1979. Bootstrap Methods: Another Look at the Jacknife. The Annals of Statistios 7(1): 1-26.

Efron, B. 1987. Better Bootstrap Confidence Intervals (with Discussion). Journal of the American Statistical Association 82: 171-200.

Finman, R. and L. Berkowitz. 1989. Some Factors Influencing the Effect of Depressed Mood on Anger and Event Hostility Toward Another. Journal of Research on Personality 23: 70-84.

Green, R. G. 1968. Effects of Frustration, Attack, and Prior Training in Aggressiveness Upon Aggressive Behavior. Journal of Personality and Social Psychology 9: $316-321$.

Greene, William H. 2002. Econometric Analysis $5^{\text {th }}$ ed. NJ: Prentice Hall.

Granger, C. W. J. and P. Newbold. 1974. Spurious Regression in Econometrics. Journal of Econometrics 2: 111-120.

Green, D. P., J. Glaser, and A. Rich. 1998. From Lynching to Gay Bashing: The Elusive Connection Between Economic Conditions and Hate Crime. Joumal of Personality and Social Psychology 75(1): 82-92.

Grenander, U. and M. Rosenblatt. 1957. Statistical Analysis of Stationary Time Series. New York: John Wiley.

Grossarth-Maticek, R., H. J. Eysenck, and H. Vetter. 1989. The Causes of Prejudice: An Empirical Study of the Frustration-Aggression Hypothesis, Personality and Individual Differences 10(5): 547-558.

Hanraty, M. A., E. O'Neal, and J. L. Sulzer. 1972. Effects of Frustration on Imitation of Aggression. Journal of Personality and Social Psychology 21: 30-34.

Honda Corporate Website. "Historical Timeline." 25 April 2010. http://corporate. honda.com/america/timeline.aspx.

Japanese American Citizens League (JACL). 2010. "A Troubling Legacy: Anti-Asian Sentiment in America," htrp://www jaclorg/public_policy/reference.htm: 9.

Kahneman, Daniel and Amos Tversky. 1979. Prospect Theory: An Analysis of Decision Under Risk. Econsmetrica 47(2): 263-291.

Miller, N. E. 1941. The Frustration Aggression Hypothesis, Psychological Review 48(4): $337-342$. 
Nelson, J., D. Gelfand, and D. Hartmann. 1969. Children's Aggression Following Competition and Exposure to an Aggressive Model. Child Development 40: 1085-1097.

Parker, D. R. and R. W. Rogers. 1981. Observation and Performance of Aggression: Effects of Multiple Models and Frustration. Personality and Social Psychology Bulletin 7: 302-308.

Phillips, P. C. B. and Joon Y. Park. 1988. Asymptotic Equivalence of Ordinary Least Squares and Generalized Least Squares in Regressions with Integrated Regressors, Journal of the American Statistical Association 83(401): 111-115. Potok, Mark. 2010. "Rage on the Right." Intelligence Report, Spring 2010, Issue Number: 137. 25 April 2010. http://www.splcenter.org/get-informed/intelligence-report/browse-all-issues/2010/spring/rage-on-the-right/

Robertson, David Brian. 2004. Bellwether Politics in Missouri. The Forum Vol. 2: Iss. 3, Article 2.

Rocha, R. F. and R. W. Rogers. 1976. Ares and Babbitt in the Classroom: Effects of Competition on Reward on Children's Aggression. Jounal of Personality and Social Psychology 33: 588-593.

Sherif, M., O. J. Harvey, B. J. White, W. R. Hood, and C. W. Sherif. 1961. Intergroup Cooperation and Competition: The Robbers Cave Experiment. Oklahoma: University Book Exchange.

Stigler, George. 1970. The Optimum Enforcement of Laws. Journal of Political Economy 78(3): 526-536.

Ulrich, R. E. 1966. Pain as the Cause of Aggression. American Zoologist 6: 643-662. US Bureau of Labor Statistics. 2010. "Local Area Unemployment Statistics. http://www.bls.gov/lau/.

US Bureau of Labor Statistics. 2010. "Local Area Unemployment Statistics 2000-2010." http://data.bls.gov/PDQ/servlet/SurveyOutputServlet?data_tool = latest_numbers\&series_id = LASST26000003.

US Census Bureau, $200 \overline{2}$ Survey of Business Ownership.

US Census Bureau. 2010. "Foreign Trade Statistics: Trade in Goods (Imports, Exports and Trade Balance) with Japan." http://www.census.gov/foreign-trade/ balance/c5880.html\#1994 (in millions).

US Census Bureau. 2010. "Foreign Trade Statistics: Trade in Goods (Imports, Exports and Trade Balance) with Korea, South." http://www.census.gov/foreign-trade/balance/c5800.html\#1994 (in millions).

US Census Bureau. 2010. "Foreign Trade Statistics: Trade in Goods (Imports, Exports and Trade Balance) with China." http://www.census.gov/foreign-trade/ balance/c5700.html\#1994 (in millions).

US Civil Rights Commission. 1992. "Civil Rights Issues Facing Asian-Americans in the 1990's," As cited in the New York Times.

Wagner, M. 2003. The Porter Hypothesis Revisited: A Literature Review of Theoretical Models and Empirical Tests. Luneburg: Center for Sustainability Management: 
2.

Who Killed Vincent Chin? Dir. Christine Choy. 1987. Film News Now Foundation/Third World Newsreel.

Williams R. B. and C. A. Clippinger. 2002. Aggression, competition, and computer games: computer and human opponents. Computers in Human Behavior 18: 495-506.

Worchel, S., V. A. Andreori, and R. Folger. 1977. Intergroup Cooperation and Intergroup Attraction: The Effect of Previous Interaction and Outcome of Combined Effort. Journal of Experimental Social Psychology 13: 131-140.

Federal Bureau of Investigation (FBI). 2010. FBI Uniform Crime Reports Hate Crimes Data. www fbi.gov/ucr/ucr.htm\#hate.

Zillmann, D. 1979. Hostility and aggression. New Jersey: Erlbaum. 


\section{ENDNOTES}

'The Chairman of Chrysler, Lee lacocca, once joked that America should drop a nucleat bomb on Japan, Japanese American Citizens League (JACL), "A Troubling Legacy: Anti-Asian Sentiment in America," p. 9.25 April 2010. herp://www jacl.org/public policy/teference.hem.

"US Civil Rights Commission, "Civil Rights Issues Facing Asian-Americans in the 1990's" (1992). as cited in the New York Times, February 29, 1992.

Southern Poverty Law Center, 2010. 25 April 2010. hetp://www.splcenter.org/get-informed/inrelligence-report/browse-all-issues/2010/spring/rage-on-the-right.

Presidential Candidate Barrack Obama, San Francisco, April 11, 2008.

'Wagner, M. 2003. The Porter Hypotheus Revisital: A Literaturr Revieve of Theorrtical Madels and Empirialt Tats. Luneburg: Center for Sustainability Management, p. 2.

Bandura, Albett. 1973. Aggresion: A Social Learning Analysis. Englewood Cliffs, NJ: Prentice-Hail See, also, the important extension of the Frustration-Aggressiojn Hypothesis due to Berkowitz, Leonard. 1989. Frustration-Aggression Hypothesis: Examination and Reformulation. Psyobological Bulletin 106(1): 59.73.

"See also Azrin, N. H., R. R. Hutchinson, and D. F. Hake, 1966. Extinction-Induced Aggression. Joarnal of the Experimental Analysis of Bebavior 9: 191-204; Azrin, N. H. R. R. Hutchinson, and R. Mclaughlin. 1965. The Opportunity for Aggression as an Operant Reinforce During Aversive Stimulation. Jaamal of Experimicntal Analysis of Bebarzor 8: 171-180; Ulrich, R. E. 1966. Pain as the Cause of Aggression. Amerzan Zoologit 6: 643.662.

See, also Sherif, M., O. J. Harvey, B. J. White, W. R. Hood, and C. W. Sherif. 1961. Intergroup Cooperation and Competition: The Robbers Cave Experiment. OK: University Book Exchange: Rocha. R. F. and R. W. Rogers 1976. Ares and Babbits in the Classroom: Effects of Competition on Reward on Children's Aggression. Journal of Personality and Sorial Psidielogy 33: 588-593, Worchel, S., V. A Andreoti, and R Folger. 1977. Intergroup Coopetation and Intergroup Attraction: The Effect of Previous Interaction and Outcome of Combined Effort. Joumal of Experimental Socal Psyboloz) 13. 131-140; Nelson. J., D. Gelfand, and D. Hartmann 1969, Children's Aggression Foltowing Competition and Exposure to an Aggressive Model. Chill Drrdopmimt 40: 1085-1097. Williams R. B and C. A. Clippinger. 2002. Aggression, Competition, and Computet Games: Computer and Human Opponents Compaters in Human Beharior 18: 495-506.

"th See also Ulrich, R. E. R. R. Hutchins, and N. H. Arzin 1965. Pain-Elicited Aggression. Pyjbslogacal Revord is $111-126$

1 See also Barron, R. A. 1977 . Homan agsressan New York: Plenum Press; Ulrich, R. E. 1966. Pain as the Cause of Aggression. American Zoologiu 6: 643-662, Ziliman, D. 1979. Hostilit) amal aggresion. NJ: Eribaum.

17. See also Green, R. G. 1968 . Effects of Frustration. Attack, and Priot training in Aggressiveness Upon Aggressive Behavior Joarnal of Perumality and Sivial Podhologo 9: 316-321. Hanracy. M. A. E. O'Neal, and J. 1. Sulzer. 1972. Eftects of Frustration on Limitation of Aggtession. Joamal of Personality and Sorial Pybology 21: 30-34; Parker. D. R., and R W. Rogers. 1981. Observation and Performance of Aggression: Effects of Multiple Models and Frustration. Perionality amd Social Psychologo Bulletin 7: 302-308. Dill, Jody C., and Craig Anderson. 1995. Effects of Frustration Justification on Hostile Aggression. Aggressive Bebavior 21: 359-369.

- See also Green, R. G. 1968 . Effects of frustration, attack, and prior training in aggressiveness upon aggressive behavior, Joumal of Personality and Social Psybology 9: 316-321. Hanraty, M. A., E. O'Neal, and J. L. Sulzer. 1972. Effects of frustration on imitation of aggression Josrnal of Personality and Secial Pyochology 21: 30-34, Parker, D. R and R. W. Rogers. 1981. Observation and performance of aggression: Effects of multiple models and frustration. Periomality and Sorial Porholog Balletin 7: $302-308$.

"1. "Losing the War with Japan." PBS Frontline documentary. 1991. http://www.youtube,com/watch?v $=$ ydDSmiSPZAs\&feature $=$ related.

15 Ader, H. J., G. J. Mellenbergh, and D. J. Hand. 2008. Advising on Research Methods: A Consultant's companton. Huizen, The Netherlands: Johannes van Kessel Publishing.

${ }^{16}$ Coleman, James S. 1987. Microfoundations and Macrosocial Behaviot. In The micro-macro link, ed. Jeffrey C. Alexander, Richard Munch, Neil J. Smelser, Berkeley, CA: University of California Press, Green, D. P., J. Glaser, and A. Rich. 1998. From Lynching to gay bashing: The elusive connection between economic conditions and hate crime, Joumal of Perionalit) and Sorial Psodolog 75(1): 82-92. Grossarth-Maticek, R., H. J. Eysenck, and H. Vetrer. 1989. The causes of prejudice: An empirical study of the frustration-aggression hypothesis. Personality and Indrudual Differences 10(5): 547-558 FBI Uniform Crime Reports Hate Crime Data. www.fbi.gov/uct/ucr.hem\#hate.

16 US Census Bureau; trade deficit with Japan from http://www.census.gov/foreign-trade/balance/ c5880.html\#1994 (in millions); trade deficit with Korea from http://www.census.gov/foreign-trade/ 
balance/c5800.heml \# 1994 (in millions); trade deficit with China from hetp://www.census.gov/foreign-trade/balance/c5700 heml\#1994 (in millions) all sources accessed 25 April 2010.

"V US Bureau of Labor Statistics. 25 April 2010, http://www.bls.gov/lau/.

20 Who Killed Vincent Chin? Dir. Christine Choy. Film News Now Foundation/Third World Newsreel, 1987.

2) US Bureau of Labor Statistics. 25 April 2010. hrtp//dara.bls.gov/PDQ/servlet/SurveyOutputServlet? dara_cool $=$ latest_numbersoseries_id $=$ LASST26000003US.

"2 Honda America. 25 April 2010. hetr://corporate honda.com/america/timeline.aspx.

"Robertson, David Brian. 2004. Bellwether Politics in Missouri. The Foram 2(3), Article 2.

2 US Census Bureau, 2002 Survey of Business Ownership. 